(7)

\title{
Interplay of Organizational Commitment and Turnover Intention in Academic Sector
}

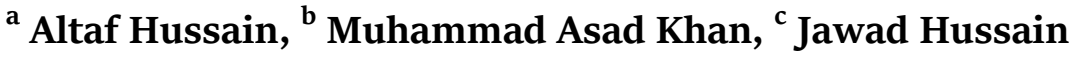 \\ a Assistant Professor, Department of Commerce and Management Sciences, University of Malakand, Khyber \\ Pakhtunkhwa, Pakistan \\ Email: altafhussain@uom.edu.pk \\ ${ }^{\mathrm{b}}$ PhD Scholar, Universiti Tun Hussein Onn (UTHM) Malaysia \\ Email: asadkhanbteo6@gmail.com \\ c Associate Professor, Department of Commerce and Management Sciences, University of Malakand, Khyber \\ Pakhtunkhwa, Pakistan \\ Email: jawadhussain79@gmail.com
}

\begin{tabular}{l}
\hline ARTICLE DETAILS \\
\hline History: \\
Accepted 16 May 2020 \\
Available Online 15 June 2020 \\
\hline Keywords: \\
Organizational, Turnover, \\
Academic Sector, SEM \\
\hline JEL Classification: \\
O11, O19, \\
\hline
\end{tabular}

DOI: $10.47067 /$ reads.v6i2.218

\begin{abstract}
Organizational commitment is considered as an important variable in the reduction of turnover of employees. It is well documented that those employees who are more committed with their respective organizations are less likely to quit those organizations. This study is aimed to examine the relationship of organizational commitment with turnover intention of academic staff as it has been less focused in academic sector of Pakistan. We collected data from 320 respondents of seven public universities located at Peshawar division, Pakistan. We used structural equation modeling (SEM) in order to analyze the collected data. Findings of our study also reported significant negative relationship between the two variables. Such results further revealed that if academic staffs are psychologically, emotionally and morally attached with their respective universities, they are less intended to quit those universities. Results also validate social exchange theory. Theoretical and practical implications are discussed in the study.
\end{abstract}

(C) 2020 The authors. Published by SPCRD Global Publishing. This is an open access article under the Creative Commons Attribution-

NonCommercial 4.0

Corresponding author's email address: altafhussain@uom.edu.pk

\section{Introduction}

Today's competitive world believes in the retention of highly performing employees in the organization. Employees retain with the organization when they are psychologically attached with it. Researchers (e.g., Bentein \& Meyer, 2004; Hafiz, 2017) believe that competitiveness and success is subject to strong organizational commitment and weak turnover intention among employees. Bartlett (2001) contends that employees' positive attitudinal and behavioral outcomes are the touchstones of effective organizational commitment. There is a vast amount of literature available which has 


\section{Review of Economics and Development Studies, Vol. 6 (2) 2020, 401-412}

discussion on the various dimensions of this organizational commitment as an attitude and a behavior. And because of this awareness organizations have seriously been taking interest in it through formulating various policies and procedures to affect it (Nehmeh, 2009). Every organization wants to retain committed employees as their loss would incur a great loss to it. When employee leaves an organization, it bears a great loss to organization both in terms of money and time (Puangyoykeaw \& Nishide, 2015).

The scholars suggested organizational commitment categorization as: “(a) a strong belief in and acceptance of the organization's goals and values; (b) a willingness to exert considerable effort on behalf of the organization; (c) a definite desire to maintain organizational membership" (Luthans, 1995; Mowday, Porter, \& Steers, 1982). If the bond of an individual with organization is strong it helps an individual retention with organization and in reduction his/her intention to quit (Allen \& Meyer, 1996). Research on organizational commitment is increasing day by day and is continued for last 50 years (Ghosh \& Swamy, 2014; Kipkebut, 2010). Some researchers such as Steers, Mowday, Porter and Boulian have made place as icons and pioneers for studying relationship of organizational commitment with turnover intention.

This study focuses on the three component model of commitment because the model has empirically been tested and investigated and has widely been acclaimed (Keskes, 2014; Pool \& Pool, 2007).

\section{Turnover intention}

Turnover is defined as "the degree of individual movement across the membership boundary of a social system" (Price, 1977, p. 4). It is also defined as movement of employee changing jobs and occupations in the job market (Abbasi \& Hollman, 2000). Researchers categorize turnover mainly into two types i.e. voluntary and involuntary but most studies mainly focus voluntary instead of involuntary turnover. Voluntary turnover is controllable and is significant for managers and practitioners (Price, 1977).

Numbers of studies have documented that turnover intention is strongly associated with organizational commitment and job satisfaction (Mohamed, Taylor, \& Hassan, 2006; Tett \& Meyer, 1993). Research on turnover concept traces back almost fifty years (Holtom, Mitchell, Lee, \& Eberly, 2008). Researchers propose that organizational commitment is an important element which affect the decision of an individual to quit or stay in the organization (Steers and Mowday, 1981).

Taking turnover intention as a part of human behavior, it affects the organization both positively and negatively. Voluntary turnover positively affect organization when low performers quit the organization and affect negatively when high performers quit the organization by resigning from their jobs and indeed it becomes a great loss for organization (Kaye \& Jordan-Evans, 2005; Park \& Shaw, 2013). Thus, turnover costs are very important from financial perspective but these costs are often hidden from the managers. The cost of voluntary turnover has not been recorded in any profit or loss statements. Rather costs are either hidden or unmeasured. Hidden costs of voluntary turnover include new recruitment and selection of employees, temporal staffing and training of new recruits while unmeasured costs include loss of customers and human capital knowledge which does not come under calculation (Alzubi, 2018; Holtom et al., 2008). Estimation of such losses is varied for every organization. The value of losses ranges from few dollars to higher salary of an individual depending on type of job, industry and replacement availability of an individual and other related factors (Hinkin \& Tracey, 200o; Kaye \& Jordan-Evans, 2005). 
Organizations invest greatly to attract and retain talented people. Hence, it is certainly unfortunate and costly when people leave organizations willingly or voluntarily. This practice has made academics and managers more conscious about employee turnover issue, specifically the voluntary nature of turnover (Major, 2016; Ton \& Huckman, 2008).

High turnover carries high costs and great loss in higher education system especially after turnover of good academicians. The loss is big because it is the loss of skilled human resource. Turnover of such skilled human resource damages the organization in terms of loss of teaching and research skills and also experience (Bester, 2008; Chughtai \& Zafar, 2006). Diverse reasons have been reported for turnover of academicians but one of the important one could be lack of organizational commitment (Ng'ethe, Iravo, \& Namusonge, 2012).

Extensive research has been carried out on the relationship of organizational commitment with turnover intention (Puangyoykeaw \& Nishide, 2015) but research on such relationship is scant in academic sector of Pakistan. Therefore, this study is aimed to find out such relationship in academic sector.

\section{Organizational commitment and turnover intention}

Organizational commitment is an important variable that predicts turnover intention of individuals working in organization. Several scholars have focused this relationship in their studies so far. Most studies have concluded strong negative relationship between these two variables (Ling, Yusof, \& Rahman, 2016; Ölçer, 2015). The logic behind this negative relationship is that when employees are psychologically attached with an organization, they would be less likely to quit the organizations. Mostly studies have investigated this relationship in industrial organizational settings and research on relationship of these two variables is scant in academic sector. Keeping in the view the previous cited literature this study also assumes negative relationship between these two variables.

\section{Problem statement}

Employee turnover is considered a serious and persistent problem within Pakistan and outside (Ahmad \& Umar, 2010; Bong, 2013; Shah, Fakhr, Ahmad, \& Zaman, 2010). It is detrimental for organizational performance when high performing employees leave the organization. This has made employers more sensitive towards retention of high performing employees (Ovadje, 20o9; Samuel \& Chipunza, 2009; Pittino, Visintin, Lenger, \& Sternad, 2016 ). If an employer fails in retaining the high performers, the only option left is to hire, select and then train the new ones (Chughtai \& Zafar, 2006; Onah \& Anikwe, 2016; Owence, Pinagase, \& Mercy, 2014).

The study conducted in public sector universities reveals that academic staff retention is a huge and crucial problem for the management of these universities and observed 9 percent of turnover which is a considerable percentage in public sector universities of Pakistan (Akhtar, Aamir, Khurshid, Abro, \& Hussain, 2015).

\section{Theoretical framework}

The framework of this study is based on two main variables i.e. organizational commitment along with its three components and turnover intention. The theoretical foundation of this study is supported by social exchange theory. Reciprocity and exchange is the foundation and mutual inclusive and interdependent element of this theory. Investment of one party affects the behavior of another party. In this study context, organizations prioritize investment in order to improve organizational 
commitment of academic staff and such enhancement of organizational commitment leads to reduced turnover intention of academic staff. A number of studies have documented negative relationship between organizational commitment and turnover intention and supports the social exchange theory.

The relationship assumed between these two variables has been depicted in Figure 1.

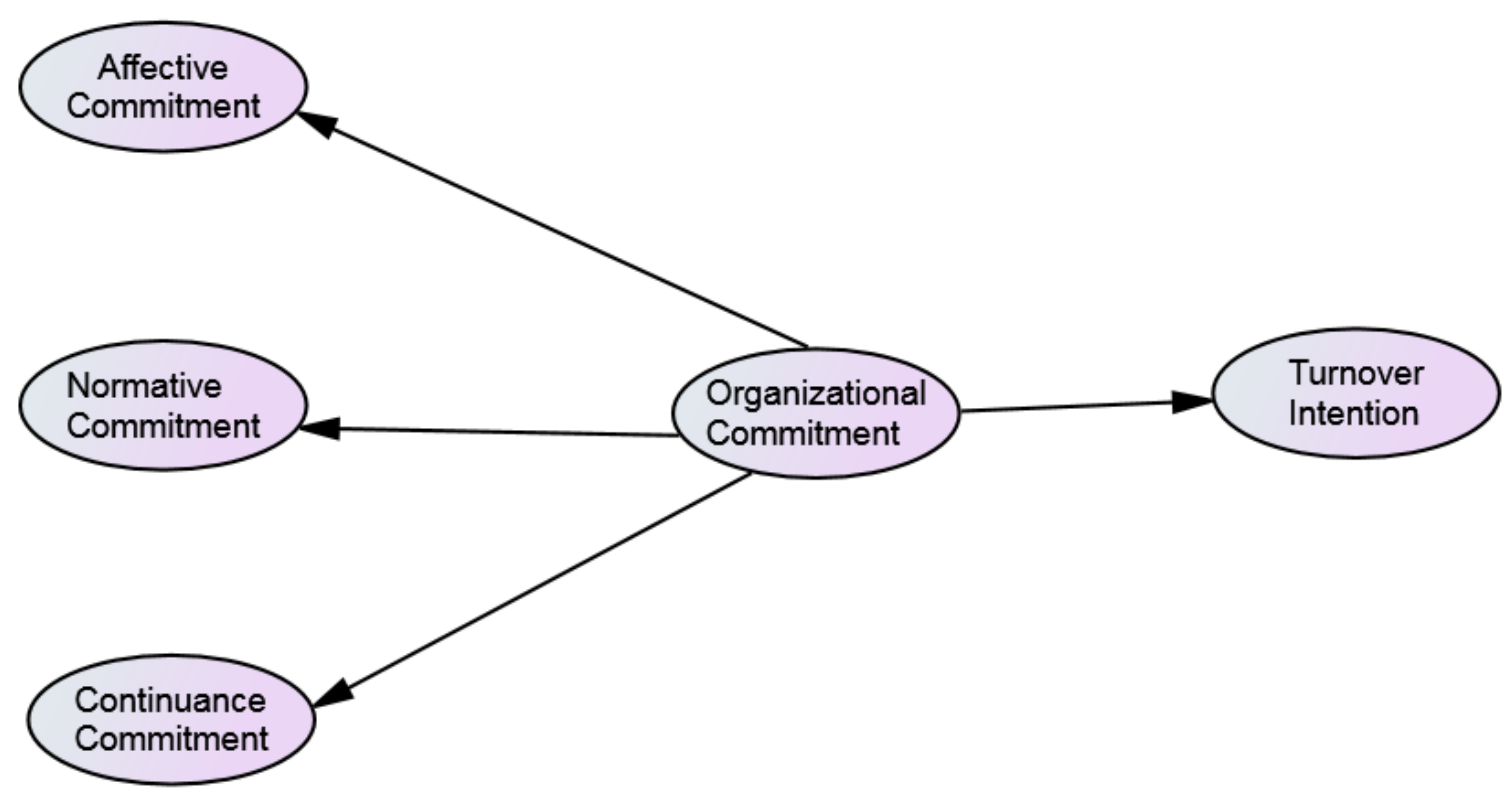

Figure 1: Conceptual framework

\section{Methodology of the study}

Survey based quantitative research design was employed in the study. We distributed questionnaires among faculty members of seven public universities of Peshawar division. Among 1922 target population, we collected data from 320 respondents recording a response rate of 65 percent. Proportionate stratified sampling technique was employed in the study. We used valid and reliable questionnaires in order to collect data. Validity and reliability of the instruments used in the study were confirmed by previous researchers. We used Allen and Meyer 1997's study for measuring organizational commitment while lee study's was employed for measuring turnover intention. We used AMOS-23 in order to analyze data of the study.

\section{Results and data analysis}

The reason of preference of SEM over first generation multiple regressions is application of technique several times separately while SEM executes mediation with single calculation of a model results. All the effects, that is, direct, indirect and total effects are assessed simultaneously and could be interpreted accordingly. 


\begin{tabular}{|l|l|l|l|l|l|}
\hline Dimensions & Items & $\begin{array}{l}\text { Factor } \\
\text { loadings }\end{array}$ & R-square & $\begin{array}{l}\text { Composite } \\
\text { reliability } \\
\text { (above 0.60) }\end{array}$ & $\begin{array}{l}\text { Average variance } \\
\text { extracted } \\
\text { (above 0.50) }\end{array}$ \\
\hline \multirow{5}{*}{$\begin{array}{l}\text { Continuance } \\
\text { commitment }\end{array}$} & $\mathrm{CC}-1$ & .61 & .37 & & \multirow{3}{*}{.86} \\
\cline { 2 - 4 } & $\mathrm{CC}-2$ & .67 & .46 & \\
\cline { 2 - 4 } & $\mathrm{CC}-4$ & .67 & .45 & \\
\cline { 2 - 4 } & $\mathrm{CC}-5$ & .67 & .45 & & \\
\cline { 2 - 4 } & $\mathrm{CC}-6$ & .83 & .69 & & \\
\cline { 2 - 4 } & $\mathrm{CC}-7$ & .80 & .64 & & \\
\hline
\end{tabular}

Table 1: Factor loadings, composite reliability and average variance extracted 
Review of Economics and Development Studies, Vol. 6 (2) 2020, 401-412

\begin{tabular}{|c|c|c|c|c|c|}
\hline \multirow{6}{*}{$\begin{array}{l}\text { Affective } \\
\text { commitment }\end{array}$} & $\mathrm{AC}-1$ & .55 & .30 & \multirow{6}{*}{.82} & \multirow{6}{*}{.50} \\
\hline & $\mathrm{AC}-2$ & .74 & .54 & & \\
\hline & $A C-3$ & .61 & .37 & & \\
\hline & $\mathrm{AC}-4$ & .69 & .47 & & \\
\hline & $\mathrm{AC}-5$ & .60 & .36 & & \\
\hline & AC- 6 & .75 & .56 & & \\
\hline \multirow{6}{*}{$\begin{array}{l}\text { Normative } \\
\text { commitment }\end{array}$} & NC-1 & .77 & .59 & \multirow{6}{*}{.89} & \multirow{6}{*}{.57} \\
\hline & NC-2 & .72 & .52 & & \\
\hline & $\mathrm{NC}-3$ & .76 & .57 & & \\
\hline & NC-4 & .81 & .66 & & \\
\hline & $\mathrm{NC}-5$ & .73 & .54 & & \\
\hline & NC-6 & .75 & .56 & & \\
\hline \multirow{8}{*}{$\begin{array}{l}\text { Turnover } \\
\text { intention }\end{array}$} & TI-1 & .72 & .52 & \multirow{8}{*}{.92} & \multirow{8}{*}{.62} \\
\hline & TI-2 & .67 & .44 & & \\
\hline & TI-3 & .88 & .77 & & \\
\hline & TI-4 & .89 & .79 & & \\
\hline & TI-5 & .83 & .69 & & \\
\hline & TI-6 & .88 & .69 & & \\
\hline & TI-7 & .73 & .53 & & \\
\hline & TI-8 & .64 & .41 & & \\
\hline
\end{tabular}

SEM can be elaborated using two-stage process, that is, measurement model and structural model. In the first stage, confirmatory factor analysis (CFA) was performed in order to validate the measurement model and to achieve the best fit measurement model for the study. The measurement model identifies the relationship between the latent variables and their observed measures or indicators. In other words, measurement model shows the linkage between the unobserved latent variables and their scores on measuring indicators (observed indictor variables). In order to validate the measurement model a number of goodness of fit statistics like, chi-square/df, normed fit index (NFI) goodness of fit index (GFI), comparative fit index (CFI), root mean square residual (RMR) and root mean square error of approximation (RMSEA) are employed in the study. Once the "best fitting" measurement model is achieved in the first stage, the researcher then validates the structural model in the second stage.

Table 2: SIC and AVE values 
Review of Economics and Development Studies, Vol. 6 (2) 2020, 401-412

In the second stage, structural models of the study were assessed through SEM using CFA. The structural model identifies the causal relationship between the latent variables (constructs). In order to

\begin{tabular}{|l|l|l|l|l|}
\hline & AC & CC & NC & TI \\
\hline $\begin{array}{l}\text { Affective } \\
\text { commitment }\end{array}$ & .707 & .714 & & \\
\hline $\begin{array}{l}\text { Continuance } \\
\text { commitment }\end{array}$ & .547 & .599 & .754 & \\
\hline $\begin{array}{l}\text { Normative } \\
\text { commitment }\end{array}$ & .537 & -.277 & -.321 & .787 \\
\hline $\begin{array}{l}\text { Turnover } \\
\text { intention }\end{array}$ & -.263 & $\mathbf{7 8 9}$ & \\
\hline
\end{tabular}

test the validity of the structural model a number of fit statistics like, chi-square/df, normed fit index (NFI), goodness of fit index (GFI), comparative fit index (CFI), root mean square residual (RMR) and root mean square error of approximation (RMSEA) are employed in the study. The values calculated by the analysis of moment structure (AMOS) are compared with the cut off values for each of the above mentioned statistics as provided by (Hair et al., 2010) and the "best fitting" structural model is attained. For detailed results refer Table 3. The use of SEM as a statistical technique in this study for analysis of hypothesized relationships seems logical as characteristics of SEM and purpose of this study has interconnection with each other.

Table 3: Statistics of model fitness

\begin{tabular}{|l|l|}
\hline Chi- square (CMIN) & $355 \cdot 935$ \\
\hline Degree of freedom (DF) & 295 \\
\hline CMIN/DF & 1.207 \\
\hline Root mean square residual (RMR) & .046 \\
\hline Root mean square error of approximation (RMSEA) & .026 \\
\hline Comparative fit index (CFI) & .986 \\
\hline Goodness of fit index (GFI) & .921 \\
\hline Normed fit index (NFI) & .926 \\
\hline Tucker lewis index (TLI) & .985 \\
\hline
\end{tabular}




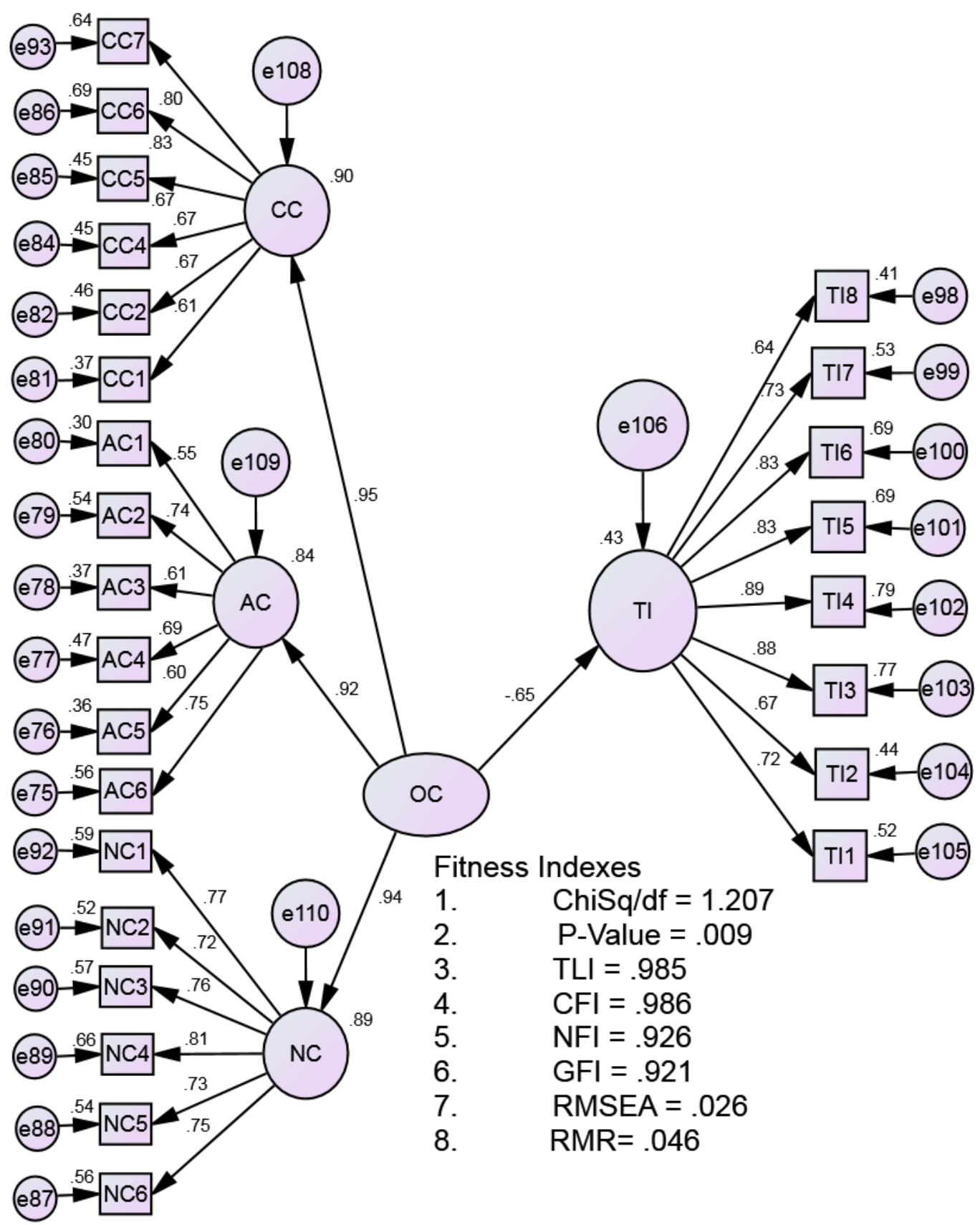

Figure 2: AMOS output showing standardized regression weights between constructs

The researcher examined in this study the relationship of organizational commitment with turnover intention. This relationship was found significant $(\mathrm{P}<0.001)$ and negative carrying standardized path coefficient of -0.65 (refer Figure 2). Thus, the hypothesis formulated in the study on relationship of two variables is strongly supported by the empirical data.

\section{Discussion}

The objective of the study was to determine the relationship of organizational commitment with turnover intention in the target population. The hypothesis made on the relationship between these two variables was tested in the study. The relationship of organizational commitment with turnover intention of academic staff was found negative and significant. Here, again the empirical evidences supported the prediction of the study. The significant and negative effect of organizational commitment on turnover intention supports the findings of previous studies regarding such relationship. The 


\section{Review of Economics and Development Studies, Vol. 6 (2) 2020, 401-412}

previous studies also reported negative relationship between these two variables (Alzubi, 2018; Jehanzeb et al., 2013; Ling et al., 2016; Newman et al., 2011; Sow, 2015). The results reported that more committed academic staff would be less intended for quitting their respective universities in comparison to non-committed academic staff. Such commitment in the academic staff with the organizations would be engendered through various tools and techniques. One such technique used by management of universities is the creation of organizational commitment among academic staff. More loyalty and commitment towards organizations creates an impression of value and importance of academic staff and also reduce intention to quit.

\section{Implications}

As, the success of organizations is not only dependent on human resource utilization, it is also dependent on the organizational ability to stimulate employees' commitment towards organization. Therefore, these results would further suggest that high level organizational commitment could be engendered in the academic staff of universities using various tools and techniques. One such tool and technique could be provision of training and development. It also clarifies to universities' management

that if they wish and intend reduction of academic staff, enhancement of organizational commitment of these academic staff would be needed on priority basis.

Turnover negatively affects the working environment and also results in negative implications (Rizwan, Arshad, Munir, Iqbal, \& Hussain, 2014; Surji, 2013). Findings of current study cautioned all stakeholders and other interested parties pertaining negative effect of turnover and advice the management to consider negative and ill effects of turnover during formulation of polices for universities.

\section{Recommendations and future research}

First, the findings of the study provide an insight that policy maker in higher education sector of Pakistan should give larger attention towards the turnover issue of academic staff which also affects the performance of the universities. It is recommended that there should be practical policy initiatives for enhancement of academic staffs' organizational commitment on priority and regular basis so that the issue of turnover could be reduced.

Second, the management of public sector universities needs to focus on the issue of turnover of academic staff. Because, if this issue is not addressed on time, then it may cause several financial hidden loss and costs in terms of recruitment and selection of new employees that would further put more financial burden on the universities.

Third, this study has presented a conceptual framework of work related attitudes and behaviors to the body of literature by combining constructs of organizational commitment and turnover intention into one research framework. Future research should consider examining organizational commitment along with its components using another comprehensive research framework combining different behavioral outcomes for which theoretical foundation is also available.

Fourth, the current study is quantitative in nature; it is recommended that future research should examine the same variables using qualitative mode of study or use mix mode of study for getting subtle findings.

\section{Conclusion}

This study contributes to the body of knowledge and literature because it proposes a model 


\section{Review of Economics and Development Studies, Vol. 6 (2) 2020, 401-412}

which identifies the relationship of organizational commitment with turnover intention of academic staff. This study further concludes that academic staff in universities faces two major problems i.e. turnover and less organizational commitment and both these problems bear negative consequences with negative effects on performance and output of organization.

The results of this study gives a clear message to the management in universities that ample amount of money should be spent on development of organizational commitment of their employees which in turn would help them in getting the excellent performance of employee considered core objective of the organization. By conducting this research on behavioral outcomes in academic sector, findings of this study would encourage and motivate leading researchers to carry forward research on this area and conclude new avenues and insights helping and benefitting academic sector.

\section{References}

Abbasi, Sami M, \& Hollman, Kenneth W. (2000). Turnover: The real bottom line. Public Personnel Management, 29(3), 333-342.

Ahmad, Aminah, \& Omar, Zoharah. (2010). Perceived family-supportive work culture, affective commitment and turnover intention of employees. Journal of American Science, 6(12), 839-846.

Akhtar, Ch Shoaib, Aamir, Alamzeb, Khurshid, Muhammad Adnan, Abro, Muhammad Moinuddin Qazi, \& Hussain, Jawad. (2015). Total Rewards and Retention: Case Study of Higher Education Institutions in Pakistan. Procedia - Social and Behavioral Sciences, 210(Supplement C), 251-259.

Allen, Natalie J, \& Meyer, John P. (1996). Affective, continuance, and normative commitment to the organization: An examination of construct validity. Journal of vocational behavior, 49(3), 252276.

Alzubi, Yazan Zayad Wanes. (2018). Turnover intentions in Jordanian Universities: The role of leadership behaviour, organizational commitment and organizational culture. International Journal of Advanced and Applied Sciences, 5(1), 177-192.

Bentein, Kathleen, \& Meyer, John. (2004). Evolution Of Commitment During Organizational Entry: A Latent Growth Modeling Approach. Administration of Science Association Canada (ASAC) Quebec, 1-16.

Bester, Coenraad. (2008). The retention of academics in the early career phase. SA Journal of Human Resource Management, 6(2), 32-41.

Bong, Wei Chen. (2013). A study on turnover intention among banks' employees in Kuching. Universiti Malaysia Sarawak,(UNIMAS).

Chughtai, Aamir Ali, \& Zafar, Sohail. (2006). Antecedents and consequences of organizational commitment among Pakistani university teachers. Applied H.R.M Research, 11(1), 39-64.

Ghosh, Sayani, \& Swamy, DR. (2014). A Literature Review on Organizational Commitment-A Comprehensive Summary. Int Journal of Engineering Research and Aplications, 4(12), 04-14.

Hafiz, AZ. (2017). Relationship between Organizational Commitment and Employee's Performance Evidence from Banking Sector of Lahore. Arabian Journal of Business and Management Review $7(2), 1-7$.

Hair, Joseph F, \& Anderson, Rolph E. (2010). Multivariate data analysis (7th ed.): Prentice Hall Higher Education.

Hinkin, Timothy R, \& Tracey, J Bruce. (2000). The cost of turnover. Cornell Hospitality Quarterly, 41(3), 14.

Holtom, Brooks C, Mitchell, Terence R, Lee, Thomas W, \& Eberly, Marion B. (2008). 5 turnover and retention research: a glance at the past, a closer review of the present, and a venture into the future. The Academy of Management Annals, 2(1), 231-274.

Jehanzeb, Khawaja, Rasheed, Anwar, \& Rasheed, Mazen F. (2013). Organizational commitment and 


\section{Review of Economics and Development Studies, Vol. 6 (2) 2020, 401-412}

turnover intentions: Impact of employee's training in private sector of Saudi Arabia. International Journal of Business and Management, 8(8), 79-90.

Kaye, Beverly, \& Jordan-Evans, Sharon. (2005). Love 'em Or Lose 'em: Getting Good People to Stay: Easyread Super Large 24pt Edition. San Francisco: Berrett-Koehler Publishers, Inc.

Keskes, Imen. (2014). Relationship between leadership styles and dimensions of employee organizational commitment: A critical review and discussion of future directions. Intangible Capital, 10(1), 26-51.

Kipkebut, Dinah Jeruto. (2010). Organisational commitment and job satisfaction in higher educational institutions: The Kenyan case. Middlesex University.

Ling, Gan Jen, Yusof, Halimah M, \& Rahman, Rabeatul Husna A. (2016). The Relationship between Organizational Commitment and Turnover Intention among Employees at a Manufacturing Company in Malaysia. International Information Institute (Tokyo). Information; Koganei, 19(8A), 3227-3231.

Luthans, F. (1995). Organizational Behaviour (7th ed.): New York: McGraw-Hill.

Major, Angel Moore. (2016). Strategies to Reduce Voluntary Employee Turnover in Small Business. Walden University.

Mohamed, Fatma, Taylor, G Stephen, \& Hassan, Ahmad. (2006). Affective commitment and intent to quit: The impact of work and non-work related issues. Journal of Managerial Issues, 18(4), 512529.

Mowday, Richard T, Porter, Lyman W, \& Steers, Richard M. (1982). Employee-organization linkages: The psychology of commitment, absenteeism, and turnover: Academic Press.

Nehmeh, Ranya. (2009). What is organizational commitment, why should managers want it in their workforce and is there any cost effective way to secure it. Swiss Management Center, 5, 45-46.

Newman, Alexander, Thanacoody, Rani, \& Hui, Wendy. (2011). The impact of employee perceptions of training on organizational commitment and turnover intentions: a study of multinationals in the Chinese service sector. The International Journal of Human Resource Management, 22(8), 17651787.

Ng'ethe, JM, Iravo, ME, \& Namusonge, GS. (2012). Determinants of academic staff retention in Public universities in Kenya: Empirical review. International Journal of Humanities and Social Science, 2(13), 205-212.

Ölçer, Ferit. (2015). THE INVESTIGATION OF THE RELATIONSHIP BETWEEN ORGANIZATIONAL JUSTICE AND TURNOVER INTENTION: THE MEDIATING ROLE OF ORGANIZATIONAL COMMITMENT. Economic computation and economic cybernetics studies and research / Academy of Economic Studies, 49, 233-251.

Ovadje, F. (2009). Exploring turnover among middle managers in a non-western context. International Journal of Business Research, 10(2), 64-80.

Owence, Chabaya, Pinagase, Tshephe Geoffrey, \& Mercy, Molotsi Matshidiso. (2014). Causes and Effects of Staff Turnover in the Academic Development Centre: A Case of a Historically Black University in South Africa. Mediterranean Journal of Social Sciences, 5(11), 69-76.

Park, T. Y., \& Shaw, J. D. . (2013). Turnover rates and organizational performance: a meta-analysis. Journal of Applied psychology, 98(2), 268-309.

Pittino, Daniel, Visintin, Francesca, Lenger, Tamara, \& Sternad, Dietmar. (2016). Are high performance work practices really necessary in family SMEs? An analysis of the impact on employee retention. Journal of Family Business Strategy, 7(2), 75-89.

Pool, Steven, \& Pool, Brian. (2007). A management development model: Measuring organizational commitment and its impact on job satisfaction among executives in a learning organization. Journal of Management Development, 26(4), 353-369.

Price, James L. (1977). The Study of Turnover (Ames, Iowa. Iowa State University. 


\section{Review of Economics and Development Studies, Vol. 6 (2) 2020, 401-412}

Puangyoykeaw, Kevalin, \& Nishide, Yuko. (2015). Organizational commitment and turnover intention in low-skilled immigrant workers in Thailand: an empirical assessment of need satisfaction, job satisfaction and overall life satisfaction factors. International Journal of Business and Management, 10(5), 98.

Rizwan, Muhammad, Arshad, Muhammad Qadeer, Munir, Hafiz Muhammad Atif, Iqbal, Faisal, \& Hussain, Atta. (2014). Determinants of Employees intention to leave: A Study from Pakistan. International Journal of Human Resource Studies, 4(3), 1-18.

Samuel, Michael O, \& Chipunza, Crispen. (2009). Employee retention and turnover: Using motivational variables as a panacea. African Journal of Business Management, 3(9), 410.

Shah, Iqtidar ALI, Fakhr, Zainab, Ahmad, M Shakil, \& Zaman, Khalid. (2010). Measuring push, pull and personal factors affecting turnover intention: a case of university teachers in Pakistan. Review of Economic and Business Studies, 3(1), 167-192.

Sow, Mouhamadou Thile. (2015). Relationship between organizational commitment and turnover intentions among healthcare internal auditors. Walden University.

Steers, R, \& Mowday, R. (1981). Employee turnover and post-decisional accomodation processes. In L. Cummings\& B. Staw (Eds.) Research in Organizational Behavior, Vol 3, Greenwich, CN: JAI Press.

Surji, Kemal. (2013). The negative effect and consequences of employee turnover and retention on the organization and its staff. European Journal of Business and Management, 5(25), 52-65.

Tett, Robert P, \& Meyer, John P. (1993). Job satisfaction, organizational commitment, turnover intention, and turnover: path analyses based on meta-analytic findings. Personnel psychology, 46(2), 259-293.

Ton, Zeynep, \& Huckman, Robert S. (2008). Managing the impact of employee turnover on performance: The role of process conformance. Organization Science, 19(1), 56-68. 